\title{
Effect of Consumption of Ground Wholeseed Flax on Human Blood Traits
}

\author{
Harbans Bhardwaj ${ }^{1}$, Anwar Hamama ${ }^{1}$, Satya Narina ${ }^{1} \&$ John Parry $^{1}$ \\ ${ }^{1}$ Agricultural Research Station, Virginia State University, Petersburg, USA \\ Correspondence: Harbans Bhardwaj, Agricultural Research Station, Virginia State University, PO Box 9061, \\ Petersburg, VA 23806, USA. Tel: 1-804-524-6723. E-mail: hbhardwj@vsu.edu
}

\author{
Received: April 12, 2012 Accepted: April 23, 2012 Online Published: July 11, 2012 \\ doi:10.5539/jas.v4n8p106 URL: http://dx.doi.org/10.5539/jas.v4n8p106
}

\begin{abstract}
Oilseed flax (Linum usitatssimum L.) has been recognized as a functional food in recent times. Functional foods deliver a health boost beyond what is expected from their traditional nutrient content. Flax fits this description perfectly because it is rich in omega-3 fatty acid and phytochemicals. Flax also provides dietary fiber and protein. We conducted an experiment in which ground wholeseed flax was consumed by 26 volunteers during 2009. A blood sample before start of consumption and one after completion of the experiment was collected and analyzed for various blood traits. Results indicated that consumption of wholeseed flax significantly increased carbon dioxide ( $24.23 \mathrm{vs.} 23.03 \mathrm{mmol} / \mathrm{L})$, lowered total serum protein $(7.17 \mathrm{vs} .7 .02 \mathrm{~d} / \mathrm{dl})$ and total Globulin $(2.99 \mathrm{vs} .2 .78 \mathrm{~g} / \mathrm{dl})$ in the blood. Flax consumption did not affect overall cholesterol and triglyceride concentrations in human blood. However, comparisons of groups of study volunteers based on three categories: those whose blood traits remained unchanged, those whose blood profile values increased upon wholeseed flax consumption, and those whose blood profile values decreased upon wholeseed flax consumption revealed that consumption of $45 \mathrm{~g}$ of wholeseed flax daily for twelve weeks decreased the concentration of total cholesterol in 9 females and 5 males, increased the concentration 5 females and 1 male, and did not affect the concentration in 2 females and 4 males. Flax consumption decreased the concentration of triglycerides in 9 females and 4 males, increased the concentration in 6 females and 4 male, and did not affect the concentration in 1 female and 2 males. These results point to the possibility that consumption of wholeseed ground flax may be helpful in reducing total cholesterol and triglycerides in females as compared to males. It was also observed that changes in concentrations of total cholesterol and triglycerides were influenced by each other - in 9 subjects concentrations of both traits were reduced, increased in 4 subjects, and remained the same in 2 subjects. We speculated that consumption of wholeseed flax for reduction of cholesterol and triglycerides in human blood may be considerably influenced by heredity.
\end{abstract}

Keywords: human health, blood profile, cholesterol, triglycerides, human subjects, flaxseed

\section{Introduction}

Anecdotal information and empirical data suggest that consumption of wholeseed flax as a food supplement could be beneficial for human health and reduce the risk of cardiovascular disease by reducing low density lipoprotein (Bloedon et al., 2008). Flax seeds are very rich in Omega-3 fatty acids. Flaxseed has been used for centuries, in many countries, as a source of food for humans and animals, and its oil has been used for nutraceutical purposes due to its high content of health beneficial components (Morris, 2007).

Flaxseed contains about $42 \%$ oil, and more than $70 \%$ is polyunsaturated fat which is considered healthy for human nutrition. Flaxseed oil contains about $53 \%$ 18:3 (n-3 fatty acid) and 13\% 18:2 (n-6 fatty acid) fatty acids (USDA, 2004). The $\alpha$-linolenic acid (also known as Alpha Linolenic Acid; 18:3n-3; Omega-3 fatty acid) which is an essential fatty acid that must be obtained from dietary sources, and foods with high levels of 18:3-n3 content are desirable for human nutrition. Oilseed flax has been recognized as a functional food in recent times. Functional foods deliver a health boost beyond what is expected from their traditional nutrient content. Flax fits this description perfectly because it is rich in omega-3 fatty acids and phytochemicals. Flax also provides dietary fiber and protein in addition to 18:3n-3 (Flax Council of Canada, 2007).

As intake of n-6 fatty acids has increased in developed countries, consumption of foods rich in n-3 fatty acids has steadily declined. Omega-3 fatty acids constitute a minuscule portion $(<1 \%)$ of the total fatty acids in U.S. food supply whereas the omega-6 fatty acids (Linoleic acid, 18:2) constitute a significant majority (Raper, 1992; Shukla 
\& Bhattacharya, 2004; Watkins, 2004). The ratio of n-6 and n-3 fatty acids is important for human health and should be 1:1 to 4:1 whereas in the Western diet it is now estimated to be 10:1 to 30:1 (Schmidt, 2001; Watkins, 2004). The amount of omega- 3 fatty acid eaten in North America no longer is sufficient to meet the needs of a healthy human body. Flaxseed oil has a very desirable omega-6: omega-3 ratio of 0.3:1.

Simopoulos (2002) addressed the issue of balancing n- 6 and n-3 fatty acids in the human diet and concluded that a balance between these fatty acids may be helpful in management of inflammatory and auto-immune diseases, coronary heart disease, depression, arthritis, aging, and cancer. Shukla and Bhattacharya (2004) indicated that addition of omega- 3 oils (fish oils) into human diet by way of encapsulated products may be undesirable due to peroxyl radicals and anisidine which are byproducts of unsaturated oil oxidation. These authors suggested that omega-3 fatty acids must be incorporated into food rather than be used as dietary supplements. Watkins (2004) summarized the information relative to $n-3$ and $n-6$ fatty acids and concluded that insufficient consumption of n-3 fatty acids in the diet may be the main cause of increased incidences of many human health disorders and that insufficiency n-3 fatty acids in western diets may be at the root of many behavioral, learning, memory, and neurological afflictions.

Research has shown that dietary consumption of flax seed lowers the risk of heart disease, prevents some forms of cancer, boosts immune system, lowers blood sugar, and provides relief from constipation (Morris, 2007). Flax seed is one of the richest plant sources of lignans which are phytoestrogens - compounds that have been shown in laboratory to help protect against certain kinds of cancer, particularly cancers of the breast and colon, by blocking tumor formation (Flax Council of Canada, 2007). The key constituents of flaxseed - the lignin secoisolariciresnol diglycoside, dietary fiber, and alpha-linolenic acid (The essential omega-3 fatty acid) are expected to be beneficial in human nutrition to reduce the risk of coronary heart disease, stroke, and cancers. On the other hand, there is a lack of precise data regarding effects of wholeseed flax consumption on human blood traits.

Our objectives were to determine effects of whole flaxseed, consumed as a food supplement, on human health. The human health, in this study, refers to traits of blood i.e. lipid profile, comprehensive metabolic profile, and complete blood count profile. It was hoped that consumption of flax will exhibit changes in blood traits relative to human health.

\section{Materials and Methods}

\subsection{Human Volunteers}

Human volunteers were recruited from Virginia State University's faculty and staff by sending a campus-wide e-mail requesting participation in this study. Faculty and staff responding to this e-mail were requested to provide information about their age and sex. Each participant was provided a code number which was used for keeping of all subsequent records. The study was initiated with 32 human volunteers, however, final results were available only from 26 subjects. This group included 10 males and 16 females with age varying from 36 to 74 years. The study was conducted from February to April in 2009. A physician was made available to the investigators by the Student Health Center of Virginia State University for technical advice and support.

\subsection{Procedures}

Effects of consuming ground wholeseed flax, as a food supplement, were determined after consumption for 12 weeks, 45 grams per day. Each participant was provided seven sealed vials on Fridays for consumption of one vial each day for the following seven days. A new set of seven vials was distributed on each Friday and the old vials were collected and discarded. Each volunteer was provided instructions (ground flaxseed was to be consumed approximately at the same time each day, ground flaxseed could be mixed with any food that is at room temperature, the vials were kept at approximately at $4^{\circ} \mathrm{C}$ in the subjects possession, and subjects were not to change their dietary pattern). Each participant provided a blood sample before start and after 12 weeks of ground wholeseed flax consumption. The blood collection and analyses were done by LabCorp (LabCorp, 1447 York Court, Burlington, NC 27215), a medical support company that provides analytical services to many physicians in the Central Virginia Area. All activities were conducted after the approval of Institutional Review Board of VSU and the Biosafety Committee of VSU. All individual results were kept confidential.

\subsection{Data Analysis}

The coded data on blood traits, from pre- and post-consumption of wholeseed ground flax seed, were compared using paired t-test at 5\% level of significance using SAS software (SAS, 1996).

\section{Results and Discussion}

The results indicated that consumption of ground wholeseed flax caused significant changes in the concentrations of BASO (white blood cells and the count may be high in allergic conditions such as asthma, hay fever, after a bee 
sting or as a response to infection), total carbon dioxide, total serum protein, total globulin, and albumin: globulin ratio in human blood. Increased concentrations of BASO (white blood cells involved in immune reaction to infections) from 0.42 vs. 0.62 (with a reference interval of 0 to 3 ) indicates some minor stress on human subjects. Increased concentration of carbon dioxide from 23.0 to 24.2 , even though minor, indicates effects of flaxseed's potential as a laxative. The albumin: globulin ratio (1:138 to 1: 54) were increased by flax consumption whereas the concentrations of total serum protein (7.18 vs. 7.01$)$ and total globulin (2.99 vs. 2.78) were decreased by flax consumption (Table 1). The pre-consumption and post-consumption concentrations of other traits of human blood were not statistically significant (Table 1). However, the pre-consumption and post-consumption concentrations varied numerically. Given the lack of statistical significance, we did not focus on all individual blood traits. However, we studied the concentrations of total cholesterol and triglycerides in more detail (Table 2).

Table 1. Blood traits in faculty and staff volunteers $(\mathrm{N}=26)$ at Virginia State University pre and post ingestion of $45 \mathrm{~g}$ ground flax per day by for 12 weeks from February to April in 2009

\begin{tabular}{|c|c|c|}
\hline Trait & Pre-ingestion & Post-ingestion \\
\hline White blood cell count & 5.84 & 5.93 \\
\hline Red blood cell count & 4.61 & 4.58 \\
\hline Hemoglobin & 13.73 & 13.74 \\
\hline Hematocrit & 40.60 & 40.60 \\
\hline Mean cell volume & 88.23 & 88.85 \\
\hline Mean cell hemoglobin & 29.85 & 30.08 \\
\hline Mean concentration, hemoglobin/RBC & 33.81 & 33.84 \\
\hline RBC distribution width & 13.77 & 14.09 \\
\hline Platelets & 237 & 242 \\
\hline Neutrophils & 55.08 & 52.62 \\
\hline Lymphs & 34.27 & 35.85 \\
\hline Monocytes & 7.15 & 6.88 \\
\hline EOS & 3.08 & 4.04 \\
\hline BASOS & 0.42 & $0.62 *$ \\
\hline Neutrophils absolute & 3.25 & $3.17 *$ \\
\hline Lymphs absolute & 1.95 & 2.05 \\
\hline Monocytes absolute & 0.43 & 0.41 \\
\hline EOS absolute & 0.20 & 0.25 \\
\hline BASO absolute & 0.02 & 0.05 \\
\hline Glucose serum & 95.77 & 97.58 \\
\hline Blood Urea N & 13.34 & 13.96 \\
\hline Creatinine serum & 0.83 & 0.83 \\
\hline BUN:Creatinine ratio & 16.50 & 17.08 \\
\hline Na serum & 141 & 140 \\
\hline K serum & 4.12 & 4.22 \\
\hline Chloride serum & 103 & 103 \\
\hline Carbon dioxide total & 23.04 & $24.23 *$ \\
\hline Calcium serum & 9.25 & 9.23 \\
\hline Protein serum & 7.18 & $7.02 *$ \\
\hline Albumin serum & 4.18 & 4.23 \\
\hline Globulin total & 2.99 & $2.78^{*}$ \\
\hline Albumin:Globulin ratio & $1 / 38$ & $1.54^{*}$ \\
\hline Bilirubin total & 0.45 & 0.47 \\
\hline Alkaline phosphates serum & 73.42 & 73.31 \\
\hline AST-SGOT & 23.04 & 20.00 \\
\hline ALT-SGPT & 26.46 & 21.65 \\
\hline Cholesterol Total & 198 & 190 \\
\hline Triglycerides & 119 & 124 \\
\hline HDL cholesterol & 52.46 & 52.69 \\
\hline VLDL cholesterol & 23.96 & 24.77 \\
\hline LDL cholesterol & 121.77 & 112.42 \\
\hline LDL:HDL ratio & 2.54 & 2.35 \\
\hline Creatinine kinase serum & 137 & 152 \\
\hline C-Reactive protein & 2.21 & 2.07 \\
\hline
\end{tabular}

* = Significant differences between pre and post values at 5 percent level. 
Table 2. Gender-related effects of ingestion of wholeseed flax on cholesterol and triglycerides concentrations in blood of 26 human volunteers

\begin{tabular}{|c|c|c|c|c|}
\hline Subject code & Sex & Age & Change in cholesterol & Change in triglycerides \\
\hline VSU-01Flax09 & $\mathrm{F}$ & 62 & Reduced & Reduced \\
\hline VSU-02Flax09 & $\mathrm{F}$ & 58 & Reduced & Reduced \\
\hline VSU-03Flax09 & M & 43 & Reduced & Reduced \\
\hline VSU-04Flax09 & M & 60 & Reduced & Reduced \\
\hline VSU-05Flax09 & $\mathrm{F}$ & 48 & Reduced & Reduced \\
\hline VSU-06Flax09 & $\mathrm{F}$ & 52 & Reduced & Reduced \\
\hline VSU-07Flax09 & $\mathrm{F}$ & 56 & Reduced & Reduced \\
\hline VSU-08Flax09 & $\mathrm{F}$ & 55 & Reduced & Reduced \\
\hline VSU-09Flax09 & $\mathrm{F}$ & 36 & Reduced & Reduced \\
\hline VSU-10Flax09 & M & 72 & Reduced & Reduced \\
\hline VSU-11Flax09 & M & 58 & Reduced & Reduced \\
\hline VSU-12Flax09 & $\mathrm{F}$ & 57 & Reduced & Reduced \\
\hline VSU-13Flax09 & $\mathrm{F}$ & 59 & Reduced & Reduced \\
\hline VSU-14Flax09 & M & 65 & Reduced & No change \\
\hline VSU-15Flax09 & M & 51 & No change & No change \\
\hline VSU-16Flax09 & $\mathrm{F}$ & 46 & No change & No change \\
\hline VSU-17Flax09 & $\mathrm{F}$ & 56 & No change & Increased \\
\hline VSU-18Flax09 & M & 66 & No change & Increased \\
\hline VSU-19Flax09 & M & 53 & No change & Increased \\
\hline VSU-20Flax09 & M & 52 & No change & Increased \\
\hline VSU-21Flax09 & $\mathrm{F}$ & 74 & Increased & Increased \\
\hline VSU-22Flax09 & $\mathrm{F}$ & 62 & Increased & Increased \\
\hline VSU-23Flax09 & $\mathrm{F}$ & 62 & Increased & Increased \\
\hline VSU-24Flax09 & $\mathrm{F}$ & 37 & Increased & Increased \\
\hline VSU-25Flax09 & M & 58 & Increased & Increased \\
\hline VSU-26Flax09 & $\mathrm{F}$ & 51 & Increased & Increased \\
\hline
\end{tabular}

Among the 26 human volunteers, consumption of $45 \mathrm{~g}$ of wholeseed flax daily for twelve weeks decreased the concentration of total cholesterol in 14 subjects ( 9 females equaling 64 percent and 5 males equaling 36 percent). Overall, cholesterol concentration was reduced in more females than males. In order to further characterize 26 subjects, the subjects were classified as those with reduced or increased cholesterol if the difference in pre and post value was greater than 5 . If the difference between pre and post value was 5 or less than the subjects were classified as those with unchanged cholesterol. In the category of subjects where cholesterol concentration was reduced (14 subjects), reduction in cholesterol concentration for females was 10 percent (224 to 201) whereas that for males was 13 percent (220 to 191). These results point to the possibility that consumption of wholeseed ground flax may be helpful in reducing total cholesterol in more females as compared to males whereas reduction in cholesterol was numerically superior for males.

The results with regard to triglycerides were also interesting. Consumption of $45 \mathrm{~g}$ of wholeseed flax daily for twelve weeks decreased the concentration of triglycerides in 13 subjects ( 9 females equaling 69 percent and 4 males equaling 31 percent), increased the concentration of triglycerides in 10 subjects ( 6 females and 4 male), and did not affect the concentration of triglycerides in 3 subjects ( 1 female and 2 males). In order to divide 26 subjects into three categories for triglyceride content, we again used 5 point difference similar to that for cholesterol content. In the category of subjects where triglyceride concentration was reduced (13 subjects), reduction in triglyceride concentration for females was 24 percent (143 to 108) whereas that for males was 26 percent (148 to 
104). These results point to the possibility that consumption of wholeseed ground flax may be helpful in reducing triglyceride in more females as compared to males whereas reduction in triglyceride concentration was numerically superior for males. Additionally, we observed that changes in concentrations of total cholesterol and triglycerides were influenced by each other - in 9 subjects concentrations of both were reduced, these concentrations were increased in 4 subjects, and these concentrations remained the same in 2 subjects.

Results with flax consumption for improving health have been inconclusive similar to our results. Ground flaxseed has been shown to reduce cholesterol levels (Bloedon et al., 2008) whereas feeding of ALA (Alpha linolenic acid) in the form of flaxseed oil fed to human beings (Kaul et al., 2008) didn't alter lipid levels. Flaxseed contains at least three components that are of health interest: soluble fibers or mucilage (Diederichsen, 2006); high amounts of ALA (Choo, 2007); and the plant lignin secoisolariciresinol diglucoside (Johnsson et al., 2000). In addition, flaxseed also contains small amounts of other lignans, namely pinoresinol, lariciresinol, and matairesinol (Zhang et al., 2008). Even though secoisolariciresinol diglucoside is the predominant lignin in flaxseed, other minor lignans may also contribute to improved health benefits (Adolphe et al., 2010). These observations lead us to suggest that research to characterize positive health effects of flaxseed ingestion would need to consider seed components and gender of human subjects.

\section{Conclusion}

Results of this preliminary study lead us to conclude that consumption of wholeseed flax may be helpful in reducing cholesterol and triglyceride concentration in human beings. However, such results may be influenced by gender of human subjects. This study was constrained by limited resources and it was not possible to follow human subjects after the study. We suggest that results of this preliminary study may not be used to suggest that increase or decrease in blood concentration of any component is healthful. Even though we recognize that over general health including liver function of volunteers would impact such studies, we were unable to determine the general health status of volunteers.

\section{Acknowledgement}

We are thankful to Virginia State University's Research Initiation Grants Program for providing financial support for this study. We acknowledge our gratefulness to Dr. Rebecca Griffin, Director of Virginia State University's Student Health Center and Dr. Irshad Ahmed, a local physician, for their technical support of this study. We, off course, are indebted to the faculty and staff volunteers who participated in this study. Contribution of Virginia State University, Agricultural Research Station Journal Article Series number 289. The use of any trade names or vendors does not imply approval to the exclusion of other products or vendors that may also be suitable.

\section{References}

Adolphe, J. L., Whiting, S. J., Juurlink, H. J. B., Lilian, U. T., \& Alcorn, J. (2010). Health effects with consumption of the flax lignin secoisolariciresinol diglucoside. British J. Nutrition, 103, 929-938 http://dx.doi.org/10.1017/S0007114509992753

Bloedon, L. T., Balikai, S., Chitttams, J., Cunnane, S. C., Berlin, J. A., Rader, D. J., \& Szapary, P. O. (2008). Flaxseed and cardiovascular risk factors: results from a double blind, randomized, controlled clinical trial. $J$. Amer. College Nutrition, 27, 65-74.

Choo, W. S. (2007). Physiological and quality characteristics of cold-pressed flaxseed oils. J. Food Composition and Analysis, 20, 202-211. http://dx.doi.org/10.1016/j.jfca.2006.12.002

Diederichsen, A. (2006). Variation of mucilage in flax seed and its relationship with other seed characters. Crop Science, 46, 365-371. http://dx.doi.org/10.2135/cropsci2005.0146

Flax Council of Canada. (2012). http://www.flaxcouncil.ca/ (Accessed February 1, 2012).

Harris, W., \& Katz, R. (2004). International workshop on omega-3 fatty acid and prevention of CHD. Inform., 15(8), 548-549.

Johnsson, P., Kamal-Eldin, A., Lundgren, L. N., \& Aman, P. (2000). HPLC method for analysis of secoisolariciresinol diglucoside in flaxseeds. Journal Agricultural and Food Chemistry, 48, 5216-5219. http://dx.doi.org/10.1021/jf0005871

Kaul, N., Kreml, R., Austria, J. A., Richard, M. N., Edel, Al., Dibrov, E., ... Pierce, G. N. (2008). A comparison of fish oil, flaxseed oil and hempseed oil supplementation on selected parameters of cardiovascular health in healthy volunteers. J. Amer. College Nutrition, 27, 51-58.

Morris, D. H. (2007). Flax-A Health and Nutrition Primer. Flax council of Canada. Available at: 
http://www.flaxcouncil.ca/english/index.jsp?p=primer\&mp=nutrition (Accessed Feb 1, 2012).

Raper, N. R., Cronin, F. J., \& Exler, J. (1992). Omega-3 fatty acid content of the US food supply. J. Amer. College Nutrition, 11(3), 304-308.

SAS. (1996). SAS System for Windows. SAS Institute, Inc., Cary, NC. [Online] Available: http://www.sas.com

Schmidt, M. A. (2001). Brain-building Nutrition. The Healing Power of Fats and Oils. $2^{\text {nd }}$ Edition. North Atlantic Books, Berkeley, California.

Shukla, V. K. S., \& Bhattacharya, K. (2004). Correcting $\omega 6 / \omega 3$ balance in human diet by Internally stabilized designer oil. AgroFOOD Industry Hi-Tech, 3, 41-43.

Simopoulos, A. P., \& Robinson, J. (1998). The Omega Plan, Harper Collins, New York. pp. 350-353.

USDA. (2004). U.S. Department of Agriculture, Agricultural Research Service, 2002.

Nutrient Database for Standard Reference. Release 15. Nutrient Data Laboratory Home Page, http://www.nal.usda.gov/fnic/foodcomp/ [Accessed February 1, 2012].

Watkins, C. (2004). Fundamental fats. Inform., 15(10), 638-640.

Zhang, W., Wang, X., Liu, Y., Haimei, T., Flickinger, B., Empie, M. W., \& Sun, S. Z. (2008). Dietary flaxseed lignin extract lowers plasma cholesterol and glucose concentrations in hypercholesterolaemic subjects. British Journal of Nutrition, 99, 1301-1309. http://dx.doi.org/10.1017/S000711450871649 